\title{
BUSINESS AND CORPORATE ELITES IN SERBIA
}

This paper discusses the issue of new business and corporate elites in Serbian society as one of the neglected aspects of two-decades-long social and economic transition away from the eyes of the general public. These elites haven't reached their status through typical channels of social mobility, such as education and achievements in professional work. In the struggle for capital allocation most of the business elites took advantage of the accelerated privatization of public property which took place in a climate of illegal business. The political establishment was in favor of the new business tycoons since they themselves also took advantage of the moment to convert their political power into the economic one. By devaluing public enterprises, selling them for a pittance and deceiving small shareholders massively, new corporate owners eroded the social capital. The society was impoverished and instead of developing it followed the path of antimodernization and peripheralization of the economy. That was a clear case of obstructing the democratic development of society by its elites. The majority of the new economic elite have originated from those social layers of the socialist era who had already possessed significant resources, economic, organizational and cultural capital, as well as political power. It can be argued that it was a transition without transformation, i.e. a process of "remaking" the old establishment into a new elite. However, since the mid-nineties, the business and corporate elites have been penetrated by a new generation of business people, generally not related to the previous establishment. They accept the rules of doing business in a responsible manner. On the other hand, the state has found enough strength to start sanctioning transitional financial frauds and fraudsters from the closed circles of the current financial (pseudo) elite.

Keywords: business elites, corporate elites, transition, transformation of elites, Serbia

\footnotetext{
* Associate Professor, Faculty of Technical Sciences, University of Novi Sad, Serbia biljananj@neobee.net.

** Associate on Science Project, Faculty of Technical Sciences, University of Novi Sad, Serbia srecko@ihrms.rs
} 


\section{Introduction}

The issue of social status, authority and the role of "new" corporate and business elites in Serbian society is still insufficiently shed light on as the phenomenon which is extremely non-transparent and hence challenging to study. These elites have emerged in a time full of contradictions in which the old (socialist) legal and ethical standards have lost their binding power, while new standards have not yet been established.

Serbian society is approaching the process of European integration with the legacy of prolonged transition ("transitology", as ironically described by Offe. ${ }^{1}$ These processes are characterized by the uncontrolled privatization under the influence of neo-liberal development strategies ${ }^{2}$, restoration of peripheral capitalism and a complete abandonment of any form of workers' participation in company management (mitbestimmung). An adequate legal framework and political environment (and even state boundaries $\left.^{3}\right)^{4}$ are still undefined. Changes in economy over the transition period have outbalanced the capacity of politics, although there is a close relationship between them. Political elites have been unable to keep pace with transformation, which has resulted in a violation of indispensable balance between political and economic elites ${ }^{5}$ : the economic elite has outbalanced the political elite, and even partly transformed into it. Economic elites have acquired great power in the dilapidated society.

It is a difficult task to provide a clear insight into new business elites without slipping from academic into the laic analysis. Business and corporate elites represent an extremely evasive social group / layer for at least two reasons: first, the important prerequisites for achieving the elite career of its actors is difficult to establish scientifically, and second, mechanisms of safeguarding their social benefits are very subtle and almost invisible. For these scientific and several nonscientific reasons, studying the business elite is one of the neglected aspects of transition. Pointing to the lack of critical thinking about the economic elite and dim controversy on effects of its operation, the social anthropologist Golubović ${ }^{6}$

1 Offe Claus(1999) Modernost i država: Istok, Zapad [Modernity and The State: East and West]. Belgrade: Filip Višnjić.

2 Mitrović Ljubiša and Veličković Dunja (2015): "Neoliberalism, inequality, and social conflicts” [„Neoliberalizam, nejednakosti i socijalni sukobi”], Godišnjak Učiteljskog fakulteta $u$ Vranju, knjiga VI/2015, 203-212.

3 It is about the problem of the southern Serbian province of Kosovo and Metohia.

4 In addition to transforming centrally planned socialist economy into the capitalist market economy, the transition also involved processes of transforming the single-party system into the democratic pluralistic system. Ehrke (2011: 153) states that most transition countries also experienced the transition of a sub-state entity of former big state association in a nation-state Tilly Charles (2005) European Revolutions: 1942-1992 [Evropske revolucije: 1942-1992]: Zagreb: Politička kultura; Podgorica: CID.

6 Golubović, Zagorka (2008). New elites [Nove elite]. Radio Free Europe, March 24. Available at: http://www.slobodnaevropa.org/content/article/1048956.html (accessed August 13, 2013). 
states that there are gaps in research of business and other elites in terms of their motives for doing what they do and not doing what they should be doing.

There is a lack of research on social characteristics, value systems, ${ }^{7}$ perceptions and economic elite actors' attitudes. As a connoisseur of the structure of society, this author ${ }^{8}$ still brings forth the view that the elites' main motive is staying in the structures of power rather than being socially positioned as value holders. ${ }^{9}$

\section{Power and authority}

Discussion on social elites is therefore also a discussion on the power relations (distribution) in society, i.e. the relationship of power and institutions, given that membership in the narrow elite, "society", requires institutional power or influential position within a prominent private or public organization. ${ }^{10}$ Power (lat. potestas - power, strength, force, but also authority) represents "the prospects of effectuating the own will within the framework of social relationship despite resistance, regardless of what these prospects are based on". ${ }^{11}$ This is why power is a highly diffuse phenomenon, difficult to "catch" and unrecognizable at first glance, and its carriers are usually hidden from the public. The nature and the subjects of power can be perceived only indirectly, by establishing mechanisms (institutions) through which it is realized. It is proved to be a problem in marking the actors of corporate and business elite and identifying their power in society. These elites have economic power, which is less visible than political power but affects political decisions. This power is based on the ownership over financial resources and their allocation. Even when this power is illegal, it is a form of actual power; the rightful potentate should always take it into account as to prevent its distribution from violating the legal order, as pointed out by Luhmann (1979). ${ }^{12}$ As opposed to the intellectual, cultural and spiritual elite, corporate and business ones coupled with the political elite possess both formal and

$7 \quad$ Although not specifying economic elites, it is necessary to note the research of Maksić and Pavlović (2011) on the value profile of the social elite towards important social issues and personal values. The research has shown that the value profile of Serbian social elite is undifferentiated since similarities between the social elite and other layers of society overcome the differences existing between them.

8 Coenen-Huter Jacques (2004) Sociologie des élites. Armand Colin.

9 However, the issue of social and primarily political elites has been the subject of decadeslong continuous research, as evidenced by the significant amount of bibliographic material (for example, Mitrović 2010, 2012; Mitrović, Veličković 2015; Bazić 2010; Cvetićanin 2010; Stanković 2010 and other).

10 According to a rough estimate, there are about 4,400 institutional positions of power in Serbia.

11 Weber Karl Emil Maximilian (1976) Economy and Society, Vol. I and II [Ekonomija i društvo, tom I i II]. Belgarde: Prosveta.

12 Luhmann Niklas (1979) Trust and power. Chichester: Wiley. 
informal (illegal) power, which is unbalanced with their level of social responsibility in terms of Carroll's four levels ${ }^{13}$ of corporate responsibility - financial, legal, ethical and philanthropic. This is also confirmed by the recent conflict between the (legal) state and political elite, who has become professional nowadays, and corporate owners and managers of state enterprises, who have acquired their initial funds and personal property in a speculative or illegal manner. ${ }^{14}$

\section{Elites in a stratified society}

Defining business elites and elites, in general, is a complex and perhaps futile task, given the "fuzzy" distinctive character of this concept. Social elites have their sociological, philosophical and politic meaning, their continuities and discontinuities, while each author tends to provide his own definition and interpretation of this term. In addition, the elites are neither a normative nor a value concept in terms of being good or bad, honest or dishonest elites. The members of the elite are not chosen basing on their positive features; what is important is the position that enables its members to make decisions, so that these elites are formed basing on 'success', rather than 'merit'. Kolabinska, ${ }^{15}$ for example, believes that the basic concept behind the term elite is that of superiority emerging from the power of doing something, but also from not doing something. The sudden change in social/class structure of Serbian society lacks operational criteria of social classification, so it is difficult to identify the relationships between elites and explicitly defined other social layers. ${ }^{16}$

The simplest definition of elite is that it consists of people who are prominent, respected and diligent. The structural definition of elites in sociological perspective, which scrupulously follows the normative approach in studying

13 Carroll B. Archie (1991) The Pyramid of Corporate Social Responsibility: Toward the Moral Management of Organizational Stakeholders. Business Horizons (July/ August): 39-48.

14 In summer of 2012, the European Commission published a list of 24 controversial privatizations of large companies in Serbia, with a request to the competent prosecutor's offices to investigate all these cases, because it is one of the issues that are expected to be resolved in "the chapter on the rule of law". This list also contained requests for auditing the privatization of 600 smaller public enterprises. The vagueness of the law on ownership transformation, especially in terms of trading in the capital market, i.e. stock market, allowed the so-called bankruptcy mafia to sell smaller stock packages on the market, but to related entities. Thus, all these packages soon found themselves in hands of a single owner.

15 Kolabinska Marie (1912) La Circulation des élites en France: étude historique depuis la fin du XI siècle jusqu'à la Grande Revolution. Lausanne: Imprimeries Réunies.

16 In recent years, a thesis has been developed about the disappearance of the middle class in Serbia. Research (Lazić 2002, 2005; Tomanović-Mihajlović 1997) have shown that this thesis is mainly wrong because in the framework of transitional changes the middle class has become endangered in only one aspect of its social status - financial situation, specifically current income - while preserving the cultural and social capital, working conditions, and lifestyle. 
the effects of market transition, provides the basic matrix and criteria for defining the elite, and these are: position, power, ownership of resources, wealth and prestige, along with the possibility of these values to be crossbred and mutually increased. Thus, Lazić ${ }^{17}$ reports that the elite is defined by the concentrated control over resources critical to the reproduction of society, but also by its active participation in the process of reproduction.

According to the usual definition, the corporate elite consists of a class of highsalaried stockholders, such as corporate CEOs, who do not necessarily have inherited privilege but have achieved high status through their careers. The concept of business elite is a somewhat broader term; in addition to corporate leaders and their managers in leading companies, it also covers the "second echelon" of business leaders, i.e. representatives of smaller enterprises, as well as directors and managers of public (state) monopolistic enterprises, who rely on state intervention and argument of social stability. This part of business elite achieves its high status based on careers in political parties. Finally, the power of corporate and business elite is based on the institution of private ownership and managerial control, ${ }^{18}$ as well as on its conjunction with state institutions.

\section{Visible and invisible elites}

Finding the main actors of Serbian business and corporate elites is always a difficult task, given the difficulties in their identification. One of the reasons for this is that the rapid privatization of public ownership and conversion of political into economic power were accomplished in the climate allowing business to be conducted in an illegal fashion. This climate was directly or indirectly supported also by the political establishment. Another reason is that, instead of being composed only of rich members, it also consists of business leaders whose influence is not proportional to their wealth. In addition, the social visibility of corporate elites is in disproportion with their power and influence. A smaller portion of its members, especially those who have come from the political establishment and are therefore already known to the public, liaise with the media, publicly announcing their personal and corporate success, revealing future plans, attending business forums and presenting academic lectures. The other, larger portion of new corporate leaders is far from the public eye and their business ventures and private life are little known to the public. Part of the business elite is networked into an influential business club, which is colloquially considered as a shadow government. With the increase in economic concentration over the

\footnotetext{
$17 \quad$ Lazić Mladen (2011) Waiting for capitalism. The emergence of new class relations in Serbia [Čekajući kapitalizam. Nastanak novih klasnih odnosa u Srbiji]. Belgrade: Službeni glasnik.

18 Mills W. Charles (1964) The Power Elite [Elita vlasti]. Kultura: Belgrade.
} 
past decade, this structure has become more closed (exclusivity of elites) ${ }^{19}$ and, as usual, tends to monopolize its potential. ${ }^{20}$

The second problem arises from choosing an appropriate method based on which elites to be identified and collecting the data of its actors. In some cases, it is necessary to combine all three methods specified by Parry ${ }^{21}$ and Putnam ${ }^{22}$ (1976; according to: Hoffmann-Lange, ${ }^{23}$ 2006: 3): the positional method (finding the relationship between formal positions and the actual power of those on leadership positions in powerful public enterprises and private organizations); the reputational method (finding the decisive actors of corporate and business layer) and the decisionmaking approach (finding the main actors of individual decisions).

\section{The origins of business and corporate elites}

Today's corporate and business elite in Serbia (often qualified as "quasielites" or "pseudo-elites") were established in the economic and political domain as early as the outset of the so-called transition from public to private ownership over the means of production. As indicated by data from various studies, ${ }^{24}$ there is a high rate of reproduction of the old economic elite - social groups who have already possessed some resources, i.e. economic, organizational and cultural capital, as well as political power. The new business elites have emerged as a result of the transformation of former (socialist) political and techno-managerial elites to economic elites, with a tendency of re-positioning themselves in the centers of political power. These processes have been interpreted by Đurković ${ }^{25}$ as a transition without any transformation, as a process of "remaking" the old establishment into the new elite. The shock therapy model

19 Scott John (ed.) (1990) The sociology of elites. Vol. 1: The study of elites. Aldershot, Edward Elgar Publishing Ltd.

20 Krysmanski Hans-Jürgen (2009): “Elites and the Monetary Power Complex". Paper given at the 7th Interdisciplinary Symposium on Knowledge and Space: "Knowledge and Power". Heidelberg, June 17-20, 2009, Department of Geography, U of Heidelberg, Klaus Tschira Foundation.

21 Parry Geraint (1969/2005) Political elites. New York: Praeger (2nd ed. with a new introduction, Essex UK: ECPR Classics.

22 Putnam D. Robert (1976) The comparative study of political elites. Englewood Cliffs NJ: Prentice-Hall

23 Hoffmann-Lange Ursula (2006): “Methodological Developments in Elite Research". Retrieved from: http://paperroom.ipsa.org/papers/paper_5308.pdf (accessed May 16, 2013).

24 Mitrović Ljubiša 2012; Cvejić Slobodan 2012; Maksić Slavica and Pavlović Slobodan 2011; Ehrke Michael 2011; Cvetićanin Neven 2010; Đurković Miša 2010; Lazić Mladen 2011, 2002, 1995; Lazić Mladen and Cvejić Slobodan 2006.

25 Đurković Miša (2010): “Transition without transformation or how the Serbian establishment became elite" [Tranzicija bez transformacije ili kako je u Srbiji od nomenklature nastala elita], Nacionalni interes, 6(3), 307-328. 
of social transition, ${ }^{26}$ privatization and institutionalization obviously suited the previous elite playing the role of the economy (pseudo)reformer of allegedly neoliberal orientation, whereas the liberal, mythical ${ }^{27}$ terms of "equal opportunities" have not been established. The reasons for this are obvious: the elite saw themselves in the role of "small capitalists" but not in that of wage workers. This example confirms the first type of elite circulation suggested by Kolabinska ${ }^{28}$ i.e. circulation that takes place between various categories of the ruling elite. Given the decreasing vertical social mobility, the second type of elite circulation suggested by Kolabinska in which individuals from the lower layers may be able to enter the existing elite, or can form new elite groups that engage in a power struggle against the existing elites, is very limited.

Hence, socialist elites were the key players in the transformation of a socialist into the capitalist social system, but without any institutional and social environment and legal order that balance this transformation between economic efficiency, social balance and general stability of society. A research ${ }^{29}$ has shown that, for example, more than two-thirds of managers in Serbia in 1993 directly or indirectly originated from the former socialist establishment. Most of them (95\%) hold higher education, and about one-fifth of them were not members of the only party that then existed. However, in the newly formed private companies the managers' educational level decreases: at the beginning of 1990 's, $57 \%$ of them hold secondary education, ${ }^{30}$ meaning that their education level was one-third lower than that of the previous directors of public enterprises. According to Bolčić, the reason for this lower level of education of the first generation of transition managers is in the small size of enterprises pursuing, at that time, trade and service industries (in $85 \%$ of cases), whereas only $15 \%$ of enterprises, at that time, were pursuing crafts and construction industries. ${ }^{31}$ Education is not the typical channel of recruiting new economic elites, neither are the actual achievements in pursuing a specific economic area, as shown later.

26 Drašković Veselin (2005): "The Priority of Economic Institutes" [Prioritet ekonomskih instituta], Ekonomski anali [Economic Annals], 165, 213-224.

$27 \quad$ Friedman Milton and Friedman D. Rose (1996) Freedom of choice [Sloboda izbora]. Novi Sad: Global Book.

28 Kolabinska Marie (1912) La Circulation des élites en France: étude historique depuis la fin $d u X I^{e}$ siècle jusqu'à la Grande Revolution. Lausanne: Imprimeries Réunies.

29 Lazić Mladen (1995): "Economic Elites in Yugoslavia at the Beginning of 90's" [Ekonomske elite u Jugoslaviji početkom devedesetih]. Sociološki pregled, 29(2), 135-148.

30 Bolčić Silvano (1993): "Social profile and features of operation of 'new managers' in Serbia in the early 1990's" [Socijalni profil i osobenosti u delovanju 'novih menadžera' u Srbiji početkom 90-tih], Luča, X/1, 55-63.

31 The suppression of the manufacturing sector is visible even a decade and a half later when private enterprises grow into corporations. As was the case in the nineties, the trade industry also prevails today. In 2009, out of 166,234 enterprises, 23,694 of them came from the industry, while 47,113 of them were pursuing trade activities. This statistic leaves out the fact that almost half of the total independent craft shops $(93,612$ out of 227,072) are also pursuing trade activities. As stated by the Serbian Business Registers Agency (2012), 105,105 active economic societies and 218,127 entrepreneurs were registered in Serbia by the end of 2012. 
Since the second half of the 1990 's, i.e. before 2000, the year which was proclaimed a year of political and economic liberalization of the country, the economic elite has experienced a mass scale penetration of individuals, members of "third" business generation, who did not belong to the previous establishment. ${ }^{32}$ This process has been further accelerated, and by 2003 the number of former socialist managers was halved.

The business and corporate elite of today's Serbian business scene consists of several groups / professions: big business owners, managers, financial and banking class, economic "professionals" recruited from international financial institutions or through other channels, mostly educated on foreign high-ranked universities and funded by the host country (considering their Serbian origin on one hand and their obligations towards the funders on the other, these people carry the hallmark of double minded syndrome; they relatively quickly disappear from the economic and political scene, but remain on positions of consultants), professionals from the diaspora and individuals "recruited" from domestic political structures. This layer also includes directors and managers of public enterprises, who "reinforce" their positions using the political power of individuals and groups from different political parties, although their sector produces annual losses to the state of around 3.5\% of GDP. Along with these structures, the membership of business and corporate elites is incorporated by individuals previously belonging to police and security agencies, as well as diplomatic and consular bodies. These elites are related by special relationship (friendship, kinship, interest) to famous individuals in the field of entertainment (music, sports, theater). According to Mills, ${ }^{33}$ celebrities do not need any further identification to support the interests of "their group", receiving thereby some benefits.

The top of a corporate elite consists of owners/shareholders and managers of successful companies that have changed the ownership structure during the transition processes in favour of foreign companies and banks, based on a pattern typical of transition economies: privatization + acquisitions in the financial (and much less in the real) sector, and Greenfield + Brownfield investments mainly in the real sector. As these elites belong rather to the global than the national type of elites, they are characterized by a highly articulated status ("Davos") culture and cosmopolitan "class consciousness". ${ }^{44}$ Therefore, it is rather a network of groups than a single monolithic entity. The very top of "domestic" corporate elite is held by corporate owners, most of whom acquired their capital in the troubled times of transition and impairment of social capital using all kinds of machinations, war profiteering, and thievery. Instead of reorganizing the economy, the business managers were trying to find ways of grabbing the greatest possible percentage of assets. ${ }^{35}$ So far, these

32 Lazić Mladen, Cvejić Slobodan (2006): "Changes in the recruitment patterns of the economic and political elites in Serbia" [Promene regrutacijskih obrazaca ekonomske i političke elite u Srbiji], Sociologija, 48(2), 97-112.

33 Mills W. Charles (1964) The Power Elite [Elita vlasti]. Kultura: Belgrade.

34 Pečujlić Miroslav (1993): “The global elite of power” [Globalna elita moći], Zbornik Matice srpske za društvene nauke, 114-115, 93-108.

35 Rus Andrej (2000): "Managerial Elite and market Transition: The Case of Slovenia", Družboslovne razprave, XVI(32-33,: 53-77. 
elites have not shown any interest in the collective good; instead, they have followed pragmatic, parochial corporate interests ${ }^{36}$ in providing benefits to their enterprises. The lower business elites were formed largely in a proportional manner, from the middle, but also upper layers, both professionals, and lower managers. They turned political power, social and cultural capital, knowledge, connections and skills into their own private capital.

This list needs to be completed by two further groups of people who played the role of "logistics" in strengthening corporate and business elites. They are professionals from economic institutes, who were involved in the privatization of public enterprises by providing economic evaluations. ${ }^{37}$ This typically means that they were involved in the degradation of social capital, as well as in the generation of corruption, which led to the decade-lasting thesis on "unsuccessful privatization", which actually means that the real price of a company at an auction, direct negotiation or through bankruptcy procedure was improperly devaluated to attract new owners. The attempt of the Serbian Academy of Sciences and Arts (SANU) to form an independent economic institute by 2011, which would be funded from public sources (instead of tycoons) and contribute to the creation of an appropriate economic and development policy, including regional development policy, failed. ${ }^{38}$

This process is also associated with commissioner elite that assessed the value and property of Serbian companies through consulting firms, indirectly or through the government's privatization agency and other financial institutions, proposed methods for selling these companies, and charged these services with high commission rates. In this process, the state remained "of short sleeves" because in the privatization of public enterprises, as well as in the secondary privatization where shares of small shareholders were bought-up, it earned tens of times less than the selling agents. ${ }^{39}$ Unković states ${ }^{40}$

36 Useem Michael (1979): “The Social Organization of the American Business Elite and Participation of Corporation Directors in the Governance of American Institutions", American Sociological Review, 44(4), 553-572.

37 In the process of privatization, these economic institutes have also become the prey of tycoons, turning thereby their profile of research institutions into consulting or audit firm engaged in the research of expert studies or promotional activities that promote and scientifically "legitimize" some partial interest (Ocić, 2012).

38 The study on the establishment of Economic Institute of SANU says that its tasks should be the following: conducting systematic fundamental research and empirical analyses, forecasting challenges that the economy and society would be facing in the near future, participating in the development of operative guidelines for the carriers of economic, social, scientific, cultural and development policy, and strategy of scientific and technological development in particular.

39 During the decade (2000-2010) of privatization in Serbia, the most earned consulting companies and financial advisers. They assessed the property and value of Serbian companies, proposed methods for selling them and charged a service fee. Consultant services were well paid, but for many companies these services were useless. Privatization in Serbia will be remembered by the vast number of canceled sales. Nearly a third of customers failed to fulfill their promise.

40 Unković Milorad (2010) International Economics [Međunarodna ekonomija]. Belgrade: Univerzitet Singidunum. 
that today the overall value of money earned by the state is equal to the value of one of the major privatized companies (for example, Lukoil). These intermediaries have become the main actors of the economic elite.

A recent research (New trends in class/layer mobility in Serbia; Cvejić have shown ${ }^{41}$ that a family background largely facilitates the acquisition of membership in the business elite (as opposed to Bottomore's utopian concept ${ }^{42}$ of future development of societies in which elites are open and recruited from different groups). While in the political elite removability has become part of the democratic political process, in the economic elite self-reproduction is much more pronounced. In about $40 \%$ of cases, members of the highest layer - entrepreneurs, directors or politicians - are actually children of members of the same layer, except that in addition to the capital they have also inherited rich social connections. In only $2 \%$ of cases, the business elite stems from workers or rural social milieu, while small and micro entrepreneurs are mostly recruited from the layer of technicians and clerks (20.3\%), qualified workers (21.2\%), and somewhat less from the layer of farmers (17.3\%).

Elite recruitment is conditioned by the prevailing patterns of social mobility. The economic and financial crisis has led to the reduction of social mobility, which in turn resulted in the establishment of hierarchy with a relatively well-defined higher, medium and lower layer. The higher layer consists of members of the "business club"; the medium layer consists of small entrepreneurs and professionals, while the lower layer includes officers, technicians, workers' layers and small farmers. The top of the hierarchy is held by large and medium-sized entrepreneurs, senior and mid-level managers and politicians. They are followed by small and micro entrepreneurs, lower managers, and large farmers. Professionals, members of freelancing occupations and lower managers that hold a university degree, follow them. The lower level consists of the layer of officers, technicians, self-employed people and freelancers. The next lower level is occupied by the layer of qualified and highly qualified workers, and unqualified workers, while the bottom of the hierarchy belongs to farmers, although they could be ranked a step higher, given that they possess some kind of economic capital.

Leaving aside the most profitable businesses in Serbia, such as top professional sports and show business, the most profitable legal job in Serbia is a managerial job, but mainly in foreign companies. However, representatives of foreign companies and headhunting agencies involved in the recruitment of top managers tend to recruit top managers from their countries because they believe that there is a deficit in the "offer" of a competent staff of this profile (especially portfolio managers, managers of financial services, etc.). Thus, for example, the top management of foreign companies employs only one person from Serbia, who often serves as a "liaison officer" with local politicians and economic establishment. ${ }^{43}$ $\overline{41}$ Cvejić Slobodan (2012): "New Trends in class mobility in Serbia in 2012", in: Šljukić Srđan and Marinković Dušan (Eds.), Social Structure and Social Mobility. Book of Abstract (pp. 18-17). Novi Sad: the University of Novi Sad, Faculty of Philosophy, Department of Sociology.

42 Botomor Tom (2008) Elites and Society [Elite i društvo]. Novi Sad: Mediteran Publishing.

43 GRUPA 484 (2010) Odliv mozgova iz Srbije - problemi i moguća rešenja [Brain drain in Serbia - challenges and possible. solutions]. Available at: http://www.grupa484.org.rs/files/2010\%20 maj\%20Grupa\%20484\%20Odliv\%20mozgovaFinal.pdf (accessed May 16, 2013). 
This situation can be explained by a number of reasons. The first one is the perennial containment of Serbia in the 1990's. This has resulted in the loss of opportunities for business interactions, the mobility of labour and its exposure to the fast moving and changing work environment, which is typical for the international business.

The second reason is in the education system, which is still "trapped" in the old and strict academic forms, so it is not ready for the long-run preparation of young people for the unknown and uncertain future and employment. It fails to answer the question of how to adapt to new situations and seek chances for new choices, improving thereby social interaction and communication, which are the main attributes of managerial areas. Researches in this area have shown ${ }^{44}$ that the education system fails to focus the attention on developing cognitive skills and abilities necessary to develop social skills and self-management skills, which are in turn necessary for any form of entrepreneurship. In addition, the financial and economic crisis has confirmed Bourdie's view ${ }^{45}$ that school education is not only an element of social mobility but also of perpetuating social inequality. While in developed countries $94 \%$ of the members of a generation attend high school, $34 \%$ attend university, and in underdeveloped countries, it makes only $2 \%$. In this respect, Serbia belongs to the group of medium developed countries, given that $11 \%$ of the population complete some form of higher education $(6.5 \%$ of them hold university degree), while $41 \%$ of population complete secondary school. $24 \%$ of the population complete primary school only, while $20 \%$ do not complete even primary school. Approximately $5 \%$ of children fail to enroll primary school, while in rural areas this percentage is higher (about 20\%). These figures are even gloomier when taking into account the high proportion of "brain drain", i.e. temporary and often permanent migration of highly skilled labour and already formed professionals, which annually reaches up to 30,000 people, ranking Serbia $24^{\text {th }}$ on the list of countries with the largest number of displaced professionals. It is, of course, a loss, rather than "mobility" or "networking" in accordance with national development interests.

The third question is related to the level of actual engagement of the members of the business elite in corporate interests and wider interests of society and public good, taking into account the fact that one of the main strategies of successful enterprises in Serbia - these are mostly telecommunication services, soft drinks producers, and tobacco and pharmaceutical industry - is implementing "compensation strategies". The absence of work motivation other than material, dedication, loyalty and frequent change of employer, is also noted by representatives of foreign companies who are distrustful towards domestic managers. In addition, corporate elites lack serious trade union partners, or form "their own" unions, or encourage union disunity in their companies, and thus, implement their particular interests in unilateral fashion, without any opposition.

\footnotetext{
$44 \quad$ Ratković Njegovan Biljana and Vukadinović Maja S (2016): “Serbian students assessing higher education in Serbia and abroad", CADMO, 1/2016, 21-41.

45 Bourdieu Pierre (1967): “School as a protector of inequality”, Gledišta, 2, 263-277.
} 


\section{Conclusion}

Business and corporate elites that have emerged in Serbia over the postsocialist period were well-positioned in the economic and political establishment at the very beginning of the so-called transition from the system of social ownership over the means of production into the system of private ownership. That was in the first place due to their newly-acquired assets. The majority of these elites were people who in the state socialism were considered to be technocrats, as well as those with a significant experience in politics. What they had in common were the percieved priorities in economic and political values, particularly embracing the concept of neoliberal economy and radical privatization.

The social reputation, power or influential capacity of a specific elite depends on its role and ability to disseminate some innovation that is particularly important for the majority of the members of a given society. Therefore, the main idea of this work is that the operation of corporate and business, i.e. economic, elites can both facilitate and obstruct the democratic development of society. This is specifically the case when elites use their influence almost exclusively for expanding corporate power and influence the political sphere, failing to be engaged in strategic issues of development priorities of Serbian society.

\section{References}

- Bazić Jovan (2010): "Political elites in the countries formed from the former Yugoslav republics - an educational profile" [Političke elite u državana nastalim iz bivših republika SFRJ - obrazovni profil], Nacionalni interes, 6(3), 367-388.

- Bolčić Silvano (1993): "Social profile and features of operation of 'new managers' in Serbia in the early 1990's" [Socijalni profil i osobenosti u delovanju 'novih menadžera' u Srbiji početkom 90-tih], Luča, X/1, 55-63.

- Botomor Tom (2008) Elites and Society [Elite i društvo]. Novi Sad: Mediteran Publishing.

- Bourdieu Pierre (1967): "School as a protector of inequality", Gledišta, 2, 263-277.

- Carroll B. Archie (1991): “The Pyramid of Corporate Social Responsibility: Toward the Moral Management of Organizational Stakeholders", Business Horizons (July/ August), 39-48.

- Coenen-Huter Jacques (2004) Sociologie des élites. Armand Colin.

- Cvejić Slobodan (2012): "New Trends in class mobility in Serbia in 2012", in: Šljukić Srđan and Marinković Dušan (Eds.), Social Structure and Social Mobility. Book of Abstract (pp. 18-17). Novi Sad: the University of Novi Sad, Faculty of Philosophy, Department of Sociology. 
- Cvetićanin Neven (2010): “The process of creating political and social elite in Serbian society - the problem of discontinuity and 'floating legitimacy" [Proces konstituisanja političke i društvene elite u srpskom društvu - problem diskontinuiteta i "fluktuirajuceg legitimiteta"], Nacionalni interes, 6(3), 107-146.

- Drašković Veselin (2005): “The Priority of Economic Institutes” [Prioritet ekonomskih instituta], Ekonomski anali [Economic Annals], 165: 213-224.

- Đurković Miša (2010): “Transition without transformation or how the Serbian establishment became elite" [Tranzicija bez transformacije ili kako je u Srbiji od nomenklature nastala elita]. Nacionalni interes, 6(3), 307-328.

- Ehrke, Michael (2011): »Oligarchs, compradores, tycoons: three tipes transition beneficiaries" [Oligarhi, kompradori, tajkuni: tri tipa dobitnika tranzicije], in: Mihailović Srećko (Ed.), Achievements of transition from socialism to capitalism [Dometi tranzicije od socijalizma do kapitalizma] (pp. 151-163). Belgrade: Friedrich Ebert Stiftung.

- Friedman Milton and Friedman D. Rose (1996) Freedom of choice [Sloboda izbora]. Novi Sad: Global Book.

- Golubović, Zagorka (2008) New elites [Nove elite]. Radio Free Europe, March 24. Available at: http://www.slobodnaevropa.org/content/article/1048956. html (accessed August 13, 2013).

- GRUPA 484 (2010) Brain drain in Serbia - challenges and possible. solutions [Odliv mozgova iz Srbije - problemi i moguća rešenja]. Available at: http:// www.grupa484.org.rs/files/2010\%20maj\%20Grupa\%20484\%20Odliv\%20mozgovaFinal.pdf (accessed May 16, 2013).

- Hoffmann-Lange Ursula (2006): "Methodological Developments in Elite Research". Retrieved from: http://paperroom.ipsa.org/papers/paper_5308. pdf (accessed May 16, 2013).

- Kolabinska Marie (1912) La Circulation des élites en France: étude historique depuis la fin du XI siècle jusqu'à la Grande Revolution. Lausanne: Imprimeries Réunies.

- Krysmanski Hans-Jürgen (2009) Elites and the Monetary Power Complex. Paper given at the 7th Interdisciplinary Symposium on Knowledge and Space: "Knowledge and Power". Heidelberg, June 17-20, 2009, Department of Geography, U of Heidelberg, Klaus Tschira Foundation.

- Lazić Mladen (2005) Changes and resistance [Promene $i$ otpori]. Beograd: „Filip Višnjić”.

- Lazić Mladen (1995): "Economic Elites in Yugoslavia at the Beginning of 90's" [Ekonomske elite u Jugoslaviji početkom devedesetih], Sociološki pregled, 29(2), 135-148.

- Lazić Mladen (2002) “(Re)structuring society in Serbia during the 1990's”, in: Bolčić Silvano and Milić Anđelka (Eds.), Serbia at the end of the millenia: destruction of the society, changes and daily life (pp. 17-34) [(Re)strukturi- 
sanje društva u Srbiji tokom 90-tih. In: Bolčić Silvano and Milić Aanđelka (Eds.), Srbija krajem milenijuma: razaranje društva, promene i svakodnevni život]. Belgrade: ISI FF.

- Lazić Mladen (2011) Waiting for capitalism. The emergence of new class relations in Serbia. [Čekajući kapitalizam. Nastanak novih klasnih odnosa u Srbiji]. Belgrade: Službeni glasnik.

- Lazić Mladen, Cvejić Slobodan (2006): "Changes in the recruitment patterns of the economic and political elites in Serbia" [Promene regrutacijskih obrazaca ekonomske i političke elite u Srbiji], Sociologija, 48(2), 97-112.

- Luhmann Niklas (1979) Trust and power. Chichester: Wiley.

- Maksić Slavica, Pavlović Zoran (2011): "Value Profile of the Social Elite in Serbia" [Vrednosni profil društvene elite u Srbiji], in: Gojkov Grozdanka and Vujasin Biljana(Eds.), Giftedness and Morality. Book of Abstracts (pp. 103-105). Vršac: Visoka škola strukovnih studija za obrazovanje vaspitača "Mihailo Palov".

- Mills W. Charles (1964) The Power Elite [Elita vlasti]. Kultura: Belgrade.

- Mitrović Ljubiša (2010): “The new bourgeoisie and its elite in society of peripheral capitalism" [Nova buržoazija i njena elita u društvu perifernog kapitalizma], Nacionalni interes, 6(3), 249-270.

- Mitrović Ljubiša (2012): "Serbian Society Between Pauperization and Oligarchization. A contribution to the research of the structure of Serbian society in transition", in: Šljukić Srđan and Marinković Dušan (Eds.), Social Structure and Social Mobility. Book of Abstract (pp. 5-6). Novi Sad: the University of Novi Sad, Faculty of Philosophy, Department of Sociology.

- Mitrović Ljubiša and Veličković Dunja (2015): "Neoliberalism, inequality and social conflicts” [„Neoliberalizam, nejednakosti i socijalni sukobi”], Godišnjak Učiteljskog fakulteta u Vranju, knjiga VI/2015, 203-212.

- Ocić Časlav (2012) Will Serbia get the SANU Institute of economic sciences? [Hoće li Srbija dobiti Institut ekonomskih nauka SANU?]. Fond Slobodana Jovanovića. Available at: http://www.slobodanjovanovic.org/2012/06/06/institutekonomskih-nauka-sanu/ (accessed May 10, 2013).

- Offe Claus (1999) Modernity and The State: East and West [Modernost $i$ država: Istok, Zapad]. Belgrade: Filip Višnjić.

- Parry Geraint (1969/2005) Political elites. New York: Praeger (2nd ed. with a new introduction, Essex UK: ECPR Classics.

- Pečujlić Miroslav (1993): “The global elite of power” [Globalna elita moći], Zbornik Matice srpske za društvene nauke, 114-115, 93-108.

- Putnam D. Robert (1976) The comparative study of political elites. Englewood Cliffs NJ: Prentice-Hall.

- Ratković Njegovan Biljana and Vukadinović Maja S (2016): "Serbian students assessing higher education in Serbia and abroad", CADMO, 1/2016, 21-41. 
- Rus Andrej (2000): "Managerial Elite and market Transition: The Case of Slovenia”, Družboslovne razprave, XVI(32-33): 53-77.

- Scott John (ed.) (1990) The sociology of elites. Vol. 1: The study of elites. Aldershot, Edward Elgar Publishing Ltd.

- Stanković Vladan (2010): "Social elites in Serbia" [Društvene elite u Srbiji], Nacionalni interes, 6(3), 469-490.

- Tomanović-Mihajlović Smiljka (1997) Childhood in Rakovica [Detinjstvo u Rakovici]. Belgrade: ISI FF.

- Tilly Charles (2005) European Revolutions: 1942-1992 [Evropske revolucije: 1942-1992]: Zagreb: Politička kultura; Podgorica: CID.

- Unković Milorad (2010) International Economics [Međunarodna ekonomija]. Belgrade: Univerzitet Singidunum.

- Useem Michael (1979): “The Social Organization of the American Business Elite and Participation of Corporation Directors in the Governance of American Institutions", American Sociological Review, 44(4): 553-572.

- Weber Karl Emil Maximilian (1976) Economy and Society, Vol. I and II [Ekonomija i društvo, tom I i II]. Belgarde: Prosveta. 


\author{
Dr Biljana Ratković NJegovan, vanRedni PROFesor \\ Fakultet tehničkih nauka, Univerzitet u Novom Sadu, Srbija. \\ Dr SRećKo STAMENKović, SARAdNiK NA NAUČNOM PROJEKTU \\ Fakultet tehničkih nauka, Univerzitet u Novom Sadu, Srbija.
}

\title{
POSLOVNE I KORPORATIVNE ELITE U SRBIJI
}

U radu se razmatra pitanje novih poslovnih i korporativnih elita u srpskom društvu, kao jedan od zanemarenih aspekata dvadesetogodišnje društvene i ekonomske tranzicije $i$ daleko od očiju naučne javnosti. Ove elite svoj status nisu dostigle uobičajenim kanalima društvene pokretliivosti, kao što su obrazovanje i postignuća u profesionalnom radu. Veći deo poslovnih elita je, u borbi za raspodelu kapitala, iskoristio ubrzanu privatizaciju društvenog vlasništva, koja se odvijala u klimi nezakonitog poslovanja. Politički establišment je išao na ruku novim privrednim bogatašima, jer je i sam iskoristio trenutak za konverziju političke u ekonomsku moć. Obezvređivanjem vrednosti društvenih preduzeća, njihovom prodajom u bescenje i masovnom prevarom malih akcionara, novi korporativni vlasnici su erodirali društveni kapital. Društvo je osiromašilo, i umesto da se razvija, krenulo je putem antimodernizacije i periferizacije privrede, što predstavlja očigledan primer opstrukcije demokratskog razvoja društva od strane elita. Nove ekonomske elite su većinom potekle od onih socijalističkih društvenih slojeva koji su već imali značajne resurse, posedovali ekonomski, organizacioni i kulturni kapital, kao i političku moć. Može se reći da je to bio proces tranzicije bez transformacije, tj. proces "presvlačenja" stare nomenklature u nove elite. Ipak, od polovine devedesetih godina prošlog veka u poslovnu i korporativnu elitu ulazi nova generacija poslovnih ljudi, koja uglavnom nije više vezana za staru nomenklaturu. Ona se prilagođava pravilima odgovornog poslovanja. S druge strane, država je smogla snage da započne sankcionisanje tranzicionih finansijskih prevara i prevaranata iz zatvorenog kruga sadašnje finansijske (pseudo) elite.

Ključne reči: poslovne elite, korporativne elite, tranzicija, transformacija elita, Srbija 